CEPAL REVIEW 88・APRIL 2006

\title{
Can the Latin American and Caribbean countries emulate the Irish model of FDI attraction?
}

\author{
Ruth Rios-Morales and David O'Donovan
}

I

the era of globalization, foreign direct investment (FDI) is an essential factor in the development of the economy. In recent years, creating a better investment climate has therefore been a policy priority for many governments, including the Latin American ones. Only a very small group of Latin American countries have attained relative success in attracting quality FDI, however. Conversely, Ireland has achieved impressive results

Ruth Rios-Morales

Research Fellow at the

School of Business Studies

and Research Associate at the

Institute for International Integration

Studies, Trinity College,

University of Dublin

•riosmorr@tcd.ie

David T. O'Donovan

Former Senior International Business

Consultant with the Industrial

Development Agency - Ireland.

Consultant to World Bank,

United Nations and the European Union

•rdavidtodonovan@eircom.net

by creating an attractive environment for FDI. The Latin American countries would do well to emulate the Irish experience, especially as regards the approach to establishing competitive advantages and efficiently promoting the country as a market site for FDI. 


\section{I}

\section{Introduction}

The process by which a small nation leveraged itself to a position among the world's leading economies in the era of globalization indeed warrants examination. One of Europe's poorest nations in the 1960s, today Ireland is one of the wealthiest nations in the world with an annual per capita income of US\$36,360 (UNDP, 2004, table 1). Ireland has built its once largely agriculturebased economy up into a sophisticated model grounded mainly on advanced technology and services. Today the industrial sector generates $47 \%$ of GDP and absorbs $28 \%$ of the workforce. The services sector contributes $46 \%$ of GDP and accounts for $65 \%$ of employment, whereas the agricultural sector represents $5 \%$ of GDP and just $7 \%$ of employment. ${ }^{1}$

In 2004, Ireland was also one of the few economies in the world to record a large trade surplus, equivalent to 38.4 billion euros (CSO, 2005). Much of this spectacular achievement has been attributed to the role of FDI in Ireland's economy. To a large extent, however, this success has resulted from a holistic approach to the implementation of industrial policies in combination with consistent macroeconomic measures, as well as a favourable external sector that attracted high-valued added FDI.

At the same time as Ireland was notching up successes, Latin America, which is regarded as the most open region in the developing world, was having an entirely different experience. After accounting for the developing world's largest share of FDI flows (14\%) in the 1970s, in the 1980s Latin America and the Caribbean began to lose its pull, capturing only $7.49 \%$ of world FDI inflows. The region's share rose again with the FDI boom of the 1990s, but never recovered the level seen in the 1970s. Since 1999, the Latin American and Caribbean region has been experiencing serious difficulties in attracting foreign investment, even though its FDI flows increased by $40 \%$ in 2004 . While the developing world in general has increased its share in FDI inflows, in 2003 Latin America's share decreased considerably, to around $8 \%$ (see table 1). More recent

${ }^{1}$ See www.idaireland.com. studies suggest that Latin America's share fell to about $6 \%$ in 2004 (IBM/PLI, 2005).

The evidence suggests that Latin American governments focused on short-term macroeconomic priorities and took a "the more the better" approach to FDI. By contrast, Ireland implemented policies that took account of long-term national development goals and aimed to attract quality investment. Most importantly, the Irish Government adopted a holistic approach to development and examined all new economic and industrial policy initiatives in the light of their probable effect on Ireland's attractiveness as an investment location.

In the era of globalization, FDI spillovers are largely absent in Latin America (ECLAC, 2003 p.20; 2004, p.29), whereas in Ireland, such spillovers were absorbed into the local economy and played an important role in economic growth.

Creating a better investment climate has been a policy priority for many governments, including the Latin American ones, in recent years. The role of FDI in a country's economy is widely recognized and, more recently, it has been acknowledged as contributing to poverty reduction. FDI alone will not produce economic development or reduce poverty, however. What it will do is generate a positive contribution to economic growth in the host country when FDI policies form part of the economic development strategy (Willem te Velde, 2001). Creating the conditions to foster economic development has produced excellent results in Ireland, and Latin America would do well to emulate the Irish experience where relevant.

This paper is intended to highlight important aspects of the Irish experience that may be applicable in Latin America. Following the introduction, section II assesses the role of FDI in the economy. Section III looks at recent trends and determinants of FDI in developing countries, section IV evaluates FDI strategies in Latin America and section V identifies policy failures in Latin America in the era of globalization. Section VI examines the Irish model of FDI attraction, highlighting the importance of the work of promotional agencies. Section VII sets out the lessons the Latin American countries can learn from the Irish experience. Section VIII contains the main conclusions and recommendations. 
TABLE 1

World: FDI inflows by regions and major countries

(Millions of dollars)

\begin{tabular}{|c|c|c|c|c|c|c|c|c|}
\hline Region/economy & $1970-1979$ & $\%$ & 1980-1989 & $\%$ & 1990-1999 & $\%$ & 2000-2004 & $\%$ \\
\hline World & 241244.2 & & 938874.0 & & 4010278.7 & & 4219336.0 & \\
\hline Developed countries & 180086.3 & 74.6 & 724613.1 & 77.2 & 2669291.8 & 66.6 & 3100554.0 & 73.5 \\
\hline Australia & 10382.9 & 4.3 & 37180.0 & 4.0 & 62154.1 & 1.5 & 83776.0 & 2.0 \\
\hline Belgium and Luxembourg & 8651.2 & 3.6 & 22451.5 & 2.4 & 227093.0 & 5.7 & 176942.0 & 4.2 \\
\hline Canada & 32346.2 & 13.4 & 37822.9 & 4.0 & 106090.9 & 2.6 & 128603.0 & 3.0 \\
\hline Denmark & 1078.6 & 0.4 & 2291.1 & 0.2 & 42604.9 & 1.1 & 43845.0 & 1.0 \\
\hline France & 14352.2 & 5.9 & 38180.6 & 4.1 & 226983.0 & 5.7 & 209577.0 & 5.0 \\
\hline Germany & 14363.9 & 6.0 & 15139.9 & 1.6 & 124615.0 & 3.1 & 263915.0 & 6.3 \\
\hline Ireland & 1370.2 & 0.6 & 2209.5 & 0.2 & 38946.1 & 1.0 & 100419.0 & 2.4 \\
\hline Italy & 5882.2 & 2.4 & 18872.7 & 2.0 & 39497.1 & 1.0 & 76020.0 & 1.8 \\
\hline Japan & 1240.0 & 0.5 & 1806.0 & 0.2 & 26318.8 & 0.7 & 37943.0 & 0.9 \\
\hline Netherlands & 9578.3 & 4.0 & 27319.3 & 2.9 & 154328.3 & 3.8 & 155545.0 & 3.7 \\
\hline Spain & 5782.9 & 2.4 & 33814.4 & 3.6 & 105723.5 & 2.6 & 158951.0 & 3.8 \\
\hline Sweden & 766.9 & 0.3 & 7063.8 & 0.8 & 130093.7 & 3.2 & 47808.0 & 1.1 \\
\hline Switzerland & 0.0 & 0.0 & 9411.1 & 1.0 & 44418.6 & 1.1 & 55430.0 & 1.3 \\
\hline United Kingdom & 32571.8 & 13.5 & 103919.5 & 11.1 & 324768.9 & 8.1 & 294114.0 & 7.0 \\
\hline United States & 32190.0 & 13.3 & 336805.0 & 35.9 & 890636.0 & 22.2 & 697492.0 & 16.5 \\
\hline Developing countries & 61091.8 & 25.3 & 213561.7 & 22.7 & 1217689.9 & 30.4 & 1026116.0 & 24.3 \\
\hline \multicolumn{9}{|l|}{ Latin America and the } \\
\hline Caribbean & 32694.5 & 13.6 & 74381.1 & 7.9 & 444322.1 & 11.1 & 351580.0 & 8.3 \\
\hline Argentina & 1305.6 & 0.5 & 5844.0 & 0.6 & 68130.5 & 1.7 & 20874.0 & 0.5 \\
\hline Brazil & 12698.4 & 5.3 & 17214.2 & 1.8 & 99216.5 & 2.5 & 100136.0 & 2.4 \\
\hline Chile & 590.6 & 0.2 & 4376.1 & 0.5 & 32466.9 & 0.8 & 23598.0 & 0.6 \\
\hline Mexico & 6015.0 & 2.5 & 23873.0 & 2.5 & 90647.5 & 2.3 & 87520.0 & 2.1 \\
\hline \multicolumn{9}{|l|}{ Venezuela (Bolivarian } \\
\hline Republic of) & -1047.9 & -0.4 & 1562.7 & 0.2 & 21426.0 & 0.5 & 13343.0 & 0.3 \\
\hline Asia and the Pacific & 17737.5 & 7.4 & 117559.1 & 12.5 & 711497.1 & 17.7 & 595794.0 & 14.1 \\
\hline China & 0.1 & 0.0 & 16186.5 & 1.7 & 290427.0 & 7.2 & 254470.0 & 6.0 \\
\hline Hong Kong, China & 2676.4 & 1.1 & 21332.7 & 2.3 & 90327.9 & 2.3 & 143041.0 & 3.4 \\
\hline India & 372.6 & 0.2 & 1047.5 & 0.1 & 15165.7 & 0.4 & 18775.0 & 0.4 \\
\hline Korea, Republic of & 1094.0 & 0.5 & 3305.0 & 0.4 & 24150.0 & 0.6 & 26730.0 & 0.6 \\
\hline Malaysia & 3261.9 & 1.4 & 9647.4 & 1.0 & 48158.0 & 1.2 & 14642.0 & 0.3 \\
\hline Singapore & 3013.0 & 1.2 & 19068.0 & 2.0 & 83989.5 & 2.1 & 61818.0 & 1.5 \\
\hline Taiwan Province of China & 658.7 & 0.3 & 4717.0 & 0.5 & 14591.0 & 0.4 & 12833.0 & 0.3 \\
\hline Thailand & 798.2 & 0.3 & 5098.6 & 0.5 & 31822.4 & 0.8 & 11199.0 & 0.3 \\
\hline Africa & 10659.8 & 4.4 & 21621.5 & 2.3 & 61870.7 & 1.5 & 78742.0 & 1.9 \\
\hline \multicolumn{9}{|l|}{ South-East Europe } \\
\hline of Independent States (CIS) &.. &.. & 78.0 & 0.0 & 52212.0 & 1.3 & 92666.0 & 2.2 \\
\hline
\end{tabular}

Source: UNCTAD (2005b). 


\section{II}

\section{The role of FDI in the economy}

In the era of globalization, FDI is regarded as an essential factor in economic development. It is conceded that FDI can generate employment, enhance exports and contribute to long-term economic development (World Bank, 2005). More recently, the spillovers of FDI have come to be considered a powerful motive for encouraging foreign investment, as FDI seems to bring knowledge, managerial skills, marketing strategies, and distribution and production networks that benefit the host economy (Blomström, 2001). For most countries, therefore, creating a better climate for FDI has become a central part of economic development.

Turning FDI into an instrument of economic development takes more than making a country an attractive market site for investment. Creating a better environment for FDI requires a holistic approach to the implementation of industrial policies (property rights legislation, reduction of red tape, and corporate tax system) and macroeconomic measures (liberalization, deregulation, availability of infrastructure and skilled labour force). The importance of policy coordination cannot be overstated. This is necessary to ensure that impacts are not diluted or even cancelled out by conflicting effects flowing from uncoordinated polices. Coordination has to take place both within and among different branches of the national government, as well as within and between different local government departments. Moreover, in order to make FDI an instrument of economic growth, long-term economic development goals have to be set in the light of national priorities. FDI will generate a positive contribution to economic growth only when the necessary conditions for economic development are implemented and the domestic economy is ready to absorb spillovers (Willem te Velde, 2001).

In some cases, the premise that FDI contributes positively to the economy by creating new jobs and fuelling economic expansion is more illusory than real. For instance, much of the FDI going to Latin America in the last few decades has been attracted by privatizations (Athukorala and Rajapatirana, 2003). This has modernized a number of sectors, but privatization represents merely a change of ownership and not necessarily an increase in physical production capability (UNCTAD, 1999). FDI has not automatically contributed to job creation or increased exports, therefore.

The positive effects of FDI on economic growth are not automatic. They depend on the host country's trade regime (Balasubramanyam, Salisu and Sapsford, 1996), level of education and human capital conditions (Borensztein, de Gregorio and Lee, 1998), technological development (De Mello, 1997), exportoriented intensity of FDI received (Willem te Velde, 2001) and macroeconomic stability (Zhang, 2001). Similarly, the assumption that FDI will always generate positive spillovers in the economy of the host country has been proven wrong. Empirical research has found that in some cases FDI spillovers can have negative effects in the host country (Aitken and Harrison, 1999; Saggi, 2000). Other studies note that potential spillovers will only materialize if local firms are primed to absorb the skills and technology generated by FDI (Blomström and Kokko, 2003; ECLAC, 2004, p.29). 


\section{III}

\section{Recent trends and determinants of FDI in developing countries}

There have been major changes in the trends and determinants of FDI worldwide. Even though developing countries gained a larger share in total inflows of FDI in the 1990s, the developed countries continue to account for the largest portion of foreign investment (see figure 1). During this period, the Latin American countries' attractiveness to investment declined somewhat, as they lost ground to countries of the AsiaPacific region, with China being the favourite for foreign investors. Today, China is the single largest recipient of FDI inflows in the developing world, attracting about $25 \%$ of total foreign investment.

A positive outlook was forecast for Central and Eastern Europe, since this region benefited in the 1990s from rapid growth of FDI inflows, but these flows have declined since 2000 (UnCTAD, 2004). Africa is experiencing similar difficulties to Latin America. Although many African countries have implemented economic reforms and policies to create a better climate for foreign investors, the region has not secured a significant volume of FDI . Notwithstanding the common argument that African countries have an FDI- hostile environment (Jenkins 2002), the real reasons for their lack of success have more to do with the fact that the determinants of FDI have changed and multiplied, and that market-site competitiveness requires efforts in many areas.

At present, a prominent characteristic of FDI is that the bulk of foreign investment in developing countries has gone to a limited number of countries (Addison and Heshmati, 2003). In the global economy, a country's overall attractiveness as a potential market site for FDI depends on the balance of benefits, costs, and risks associated with doing business there. Although the rapid growth of the global economy has changed the factors that influence FDI in developing countries, the longstanding determinants of foreign investment, such as natural resources, country location and infrastructure, remain important in the assessment of a potential market site (Nunnenkamp and Spatz, 2002). Nevertheless, these longstanding determinants are not sufficient in themselves to create an attractive market for FDI.

A long list of requirements have to be met in order to create a better climate for FDI. Recent literature on

FIGURE 1

World: FDI trends, 1970-2004

(Millions of dollars)
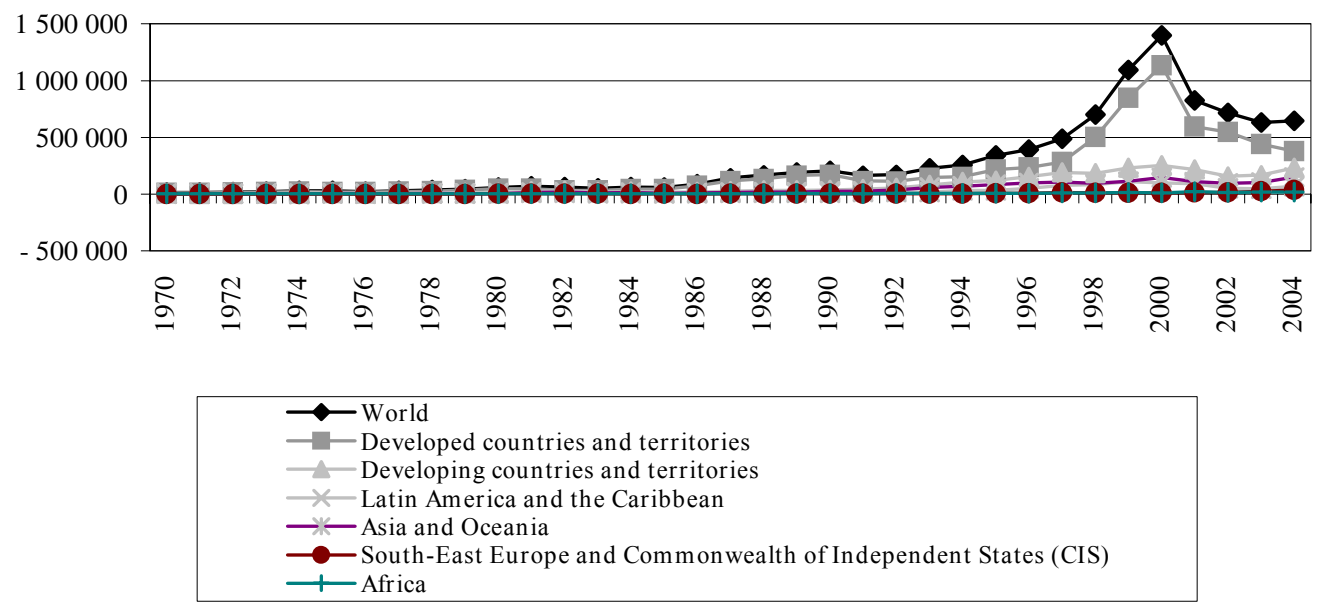

Source: UNCTAD (2005b). 
this topic identifies institutional features as new and significant determinants of FDI. Such features include the degree of political stability, government intervention in the economy, trade openness, property rights legislation, red tape and the corporate tax system (De Mello, 1997; Rodrik, Subramanian and Trebbi, 2002). Recent work on incentives for FDI signal corruption as an important deterrent (Mauro, 1995; Oman, 2000; Church, Gandal and Krause, 2002), even though some countries have succeeded in attracting foreign investment despite evidence of this problem (Kolstad and Villanger, 2004). This suggests that certain market site characteristics are associated and weighted differently by investors balancing the benefits, costs, and risks associated with foreign investment.

Education and training are also new and important factors on the list of determinants of FDI in developing countries. Numerous studies ${ }^{2}$ have identified education and training as vital influences on FDI in the new global economy. For instance, an influential research report prepared by Professor Magnus Blomström and published by the Organisation for Economic Cooperation and Development (OECD) concludes that developing country governments should focus on education and training in order to create the strongest potential market site for FDI (Blomström M. 2001, p. 178). By enhancing education and, hence, human capital, governments can encourage export-oriented FDI and thus help to maintain macroeconomic stability (Zhang, 2001).

Regional and bilateral agreements have also been important in improving the investment climate in many countries (Ethier, 1998). The number of trade agreements signed by developing countries has increased dramatically in recent times. According to the World Investment Report 2005 (UNCTAD, 2005a), more than 2,392 bilateral investment treaties now exist. The World Trade Organization (WTO) estimates that over 300 regional trade agreements will be in effect by 2007. ${ }^{3}$ Regional agreements have important influence on the location of foreign investment. Research conducted by Hallward-Driemeier (2003) empirically tested the influence of bilateral agreements on increasing FDI inflows to developing countries and concluded that such treaties complement good institutional features, but cannot substitute for them.

\section{IV}

\section{FDI strategies in Latin America and the Caribbean}

A modified version of Dunning's model (1988) will be used to assess different factors involved in attracting FDI in Latin America and the Caribbean in the recent period. This version of the model categorizes FDI by four different strategies, depending on the objective it seeks: (i) access to natural resources; (ii) market expansion; (iii) greater efficiency; or (iv) technological assets. In recent years, the Latin American and Caribbean region has attracted FDI seeking natural resources, market expansion and efficiency. Efficiencyseeking FDI is most prominent in Latin America's foreign trade and has been attracted by only a few countries. No significant technological asset-seeking investment appears to have been recorded in Latin America.

\footnotetext{
2 Borensztein, De Gregorio and Lee (1998); Noorbakhsh, Paloni and Youssef (2001); Blomström (2001); Zhang (2001); Addison and Heshmati (2003).
}

\section{Natural resource-seeking investment}

During the last 100 years, natural resources have been the main driver of FDI in Latin America (ECLAC, 2004). TNCs have invested in petroleum, gas, and the mining industry, particularly in the Southern Cone (see table 2).

Lately, foreign investors have shown mounting interest in exploiting natural gas. Since the discovery of gas reserves in Argentina, Bolivia, Brazil, Ecuador, Colombia and Peru in the 1990s, international hydrocarbons firms have become increasingly keen to invest in gas in the southern part of the region. The French company Totalfina has been the largest investor in the sector, exploring and exploiting hydrocarbon reserves mainly in Argentina, Bolivarian Republic of Venezuela, Bolivia, Colombia and Trinidad and Tobago. Petrobas, a Brazilian State-controlled Latin American

\footnotetext{
${ }^{3}$ See http://www.wto.org/english/tratop_e/region_e/regfac_e.htm.
} 
TABLE 2

Latin America and the Caribbean: FDI strategies

\begin{tabular}{|c|c|c|c|}
\hline Strategies & Natural resource-seeking & Local market-seeking & Efficiency-seeking \\
\hline \multicolumn{4}{|l|}{ Sectors } \\
\hline \multirow[t]{5}{*}{ Goods } & $\begin{array}{l}\text { Petroleum and gas: } \\
\text { Andean Community, }\end{array}$ & Automotive: MERCOSUR & Automotive: Mexico \\
\hline & Argentina, Trinidad and Tobago & Chemical: Brazil & Electronics: Mexico and Caribbean Basin \\
\hline & $\begin{array}{l}\text { Mining: Andean Community, } \\
\text { Chile and Argentina }\end{array}$ & $\begin{array}{l}\text { Food industry: Argentina, Brazil } \\
\text { and Mexico }\end{array}$ & Clothing: Mexico and Caribbean Basin \\
\hline & & $\begin{array}{l}\text { Beverages: Argentina, Brazil } \\
\text { and Mexico }\end{array}$ & \\
\hline & & $\begin{array}{l}\text { Tobacco: Argentina, Brazil } \\
\text { and Mexico }\end{array}$ & \\
\hline \multirow[t]{5}{*}{ Services } & $\begin{array}{l}\text { Tourism: Mexico and the } \\
\text { Caribbean Basin }\end{array}$ & $\begin{array}{l}\text { Finance: Argentina, Bolivarian } \\
\text { Republic of Venezuela, Brazil, } \\
\text { Chile, Colombia, Mexico } \\
\text { and Peru }\end{array}$ & Back-office services: Costa Rica \\
\hline & & $\begin{array}{l}\text { Telecoms: Argentina, Bolivarian } \\
\text { Republic of Venezuela, Brazil, Chile } \\
\text { and Peru }\end{array}$ & \\
\hline & & $\begin{array}{l}\text { Retail commerce: Argentina, Brazil } \\
\text { and Mexico }\end{array}$ & \\
\hline & & $\begin{array}{l}\text { Electric power: Argentina, Brazil, } \\
\text { Chile, Colombia and Central America }\end{array}$ & \\
\hline & & $\begin{array}{l}\text { Gas distribution: Argentina, Bolivia, } \\
\text { Chile and Colombia }\end{array}$ & \\
\hline
\end{tabular}

Source: ECLAC (2005, table I.6).

$\mathrm{TNC}$, is a key player in the development of the region's gas industry. Petrobas has invested in Angola, Argentina, Bolivarian Republic of Venezuela, Bolivia, Ecuador, Nigeria, Peru and the United States, and ranks number 144 among the world's top 500 firms (ECLAC, 2004). Mexico and the Caribbean Basin were the main market sites for FDI in the tourist sector.

Most natural resources continue to be exported mainly as raw material. This type of investment therefore creates very little value added in the Latin American economies (ECLAC, 2004). Consequently, positive-spillover effects in terms of technology transfer and absorption, production linkages, human resources training and local business development have been lacking in the region (ECLAC, 2004, p.43). Foreign Investment in Latin America and the Caribbean, 2004 (ECLAC, 2005) notes that spillover has been absent even in Mexico and the Caribbean Basin, which have succeeded in attracting efficiency-seeking investment.

\section{Market-seeking investment}

Local market-seeking companies invest more in Latin America, proportionally speaking, than the other categories of investors. TNC food manufacturers have targeted markets with large populations, such as Brazil, Mexico and Argentina, while the Southern Common Market (MERCOSUR) ${ }^{4}$ has attracted the automotive industry (see table 2). The most prominent firms, however, are those seeking local markets in the services sector. These companies have invested mainly in the banking system, telecommunications, electric power and gas distribution.

During the period 1996-2003, the distribution of FDI flows coming into Latin America and the Caribbean

\footnotetext{
${ }^{4}$ In March 1991, Argentina, Brazil, Paraguay and Uruguay signed the Treaty of Asunción creating MERCOSUR, which has opened up opportunities for firms to expand their markets.
} 
shifted towards services, which accounted for $59 \%$ of total inflows, while manufacturing received $28 \%$ and the primary sector $13 \%$ (ECLAC, 2004). The main sources of FDI flows into Latin America and the Caribbean have also changed. Although the United States continues to be the largest single contributor, accounting for about $33 \%$ of total FDI in the region (ECLAC, 2004), investment from Europe has grown strongly since the privatizations. Spain is now the second largest source of FDI, contributing $16 \%$ of the total. Investors from France, the Netherlands and the United Kingdom also have a presence in the region.

Spanish firms are the key players in the services sector, especially in the telecoms industry and the banking system. The Spanish banks Santander Central Hispano ( $\mathrm{SCH}$ ) and Bilbao Vizcaya Argentaria (BBVA) own $52 \%$ of the assets of the region's top 10 transnational banks (ECLAC, 2005). In the telecoms industry, Telefónica of Spain's recent purchase of the United States mobile phone company BellSouth enabled the Spanish firm to maintain its lead position in the sector. In electric power and gas distribution, Endesa of Spain is among the leading foreign firms that occupy dominant positions in the Southern Cone, except in Brazil.

\section{Efficiency-seeking investment}

Efficiency-seeking investment has proven more difficult to attract in Latin America. Mexico and the Caribbean Basin form the only subregion to have received FDI seeking efficiency in goods production. Such investment in Mexico goes to the automotive, electronics and clothing industries and has been strengthened by the North American Free Trade Agreement (NAFTA). By contrast, the Caribbean Basin attracts this type of investment mainly in clothing and, to some extent, electronics. The Central American Free Trade Agreement (CAFTA) will not substantially alter that pattern. The Intel semiconductor assembly and testing plant in Costa Rica is an example of investment in electronics.

Although investment in this subregion has boosted its exports, it has produced little in the way of positive spillover in terms of technology transfer and absorption, production linkages, human resources training and local business development (ECLAC, 2004 p. 43). Costa Rica has been successful in attracting efficiency-seeking FDI in the service sector, whose exports have been driven by back-office and call centre services. This small country of 3.5 million inhabitants marketed itself on the basis of its political and economic stability, highly educated young people and proximity to the northern market.

\section{V}

\section{Policies used to attract FDI in Latin America}

\section{and the Caribbean}

Over the past 15 years, the Latin American and Caribbean share in FDI inflows has waned, showing that, in practice, most of the countries' incentives policies were of limited effectiveness in attracting FDI in today's competitive market. To a lesser extent, the lack of success was also the result of a poor policy approach to FDI, since the governments were more concerned with short-term macroeconomic priorities than with longterm economic development. A large proportion of the FDI received in the region has come in the form of acquisitions of existing companies (Athukorala and Rajapatirana, 2003), sometimes as part of privatization programmes (ECLAC, 2004). Greenfield investment, which is the type that creates new plants, increases productive capacity and provides greater economic value, has been very limited.
Much has changed since Latin America was the developing region of choice for foreign investors. During the 1980s, a number of countries began to promote FDI by means of macroeconomic polices and industrial mechanisms, including low taxes, grants and loans for foreign investors, in some cases going so far as to extend monopoly rights (Blomström, 2001). Ever since, a market site's attractiveness has been about more than the availability of natural resources and open market policies (liberalization, privatization and deregulation of the economy), since investors have been able to find markets offering more benefits and lower costs and risks. Clearly, it was during this period that Latin America's pull as a market site began to weaken and its share in FDI inflows began a drastic decline that lasted until 2004. 
Like in other world regions, FDI flows into Latin America have been largely confined to a small group of countries: Brazil, Mexico, Argentina and Chile. In 2003, Brazil received the highest percentage of FDI in Latin America, determined largely by its domestic market size and potential as a base for exports to other countries in the region. ${ }^{5}$ The second largest recipient of FDI in Latin America is Mexico, whose competitiveness has been enhanced by trade agreements, principally NAFTA. Argentina has been the country hardest hit by the decline of FDI inflows to the region since 1999 (see figure 2). Although its economy has started to pick up again, Argentina is still far from regaining the levels of FDI seen before the financial crisis (UNCTAD, 2004). In 2003, Chile was one of the few countries in the world to increase its FDI share. Since 2001, FDI in Chile has benefited from the country's stable economy and dynamic business environment anchored in strong institutions. The drop in FDI recorded in 2000 reflected a return to more normal levels after exceptionally high inflows in 1999.

We have identified three factors that explain why the Latin American countries are currently facing difficulties in attracting FDI. First, in the era of globalization, natural resources alone are insufficient to create an attractive investment climate in the region. For over 100 years, Latin America received FDI mainly because of its natural resources (ECLAC, 2004). In the past, natural resource-seeking investors gravitated to places where raw materials and minerals were found. Today, investors still seek natural resources, but they also consider the availability of low-cost labour, a skilled workforce and quality physical infrastructure (Kinoshita and Campos, 2004). Another important reason why natural resources do not in themselves add up to an attractive investment climate is price volatility, since Latin America's natural resources are exported largely as raw materials, which does not generate value added for the economies (ECLAC, 2003).

Second, serious failures have occurred in the promotion of efficiency-seeking investment. Efficiencyseeking investors focus on labour productivity, resource and input costs and the country's participation in regional integration frameworks (Dunning, 1988). In the 1990s, Latin America was concerned mainly with recovering from the decade before and neglected important aspects that have now become crucial determinants of FDI. While their competitors for FDI were pursuing growth-enabling macroeconomic policies, the Latin American countries employed tight monetary and fiscal policies that helped to hold down rates of economic growth and investment (UNCTAD, 2004, p. 620).

Education and training were high priorities for the “Asian Tigers" (Addison and Heshmati, 2003), whereas

FIGURE 2

Latin America: main recipients of FDI, 1970-2004

(Millions of dollars)

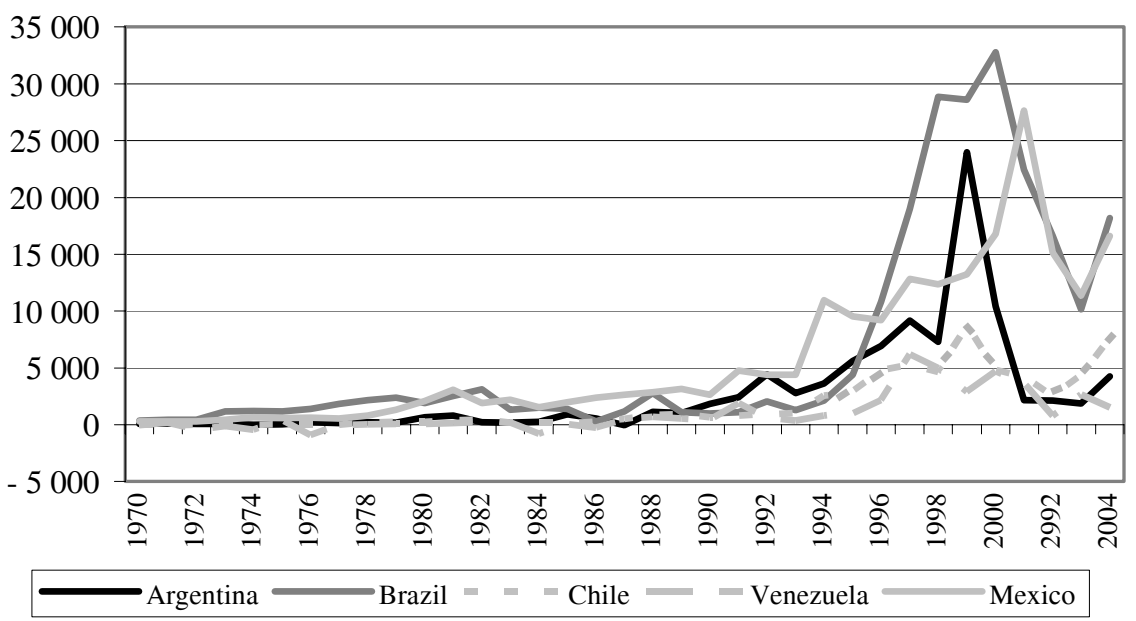

Source: UNCTAD (2005b).

${ }^{5}$ The main recipient of FDI in Brazil was the food and beverage industry, followed by telecoms services. The largest investors are from the
Netherlands (45\%) and the United States (17\%), although Spanish, French and Mexican investors have also established a presence. 
labour market training was largely absent from the FDI policies of most Latin American countries, despite the region's human capital potential: for example, adult literacy averages $88.6 \%$ in Latin America, not far from the average Asian rate of $90.3 \%$, and Latin America has the developing world's highest score in the Human Development Index, at 0.777 , compared with the average rate of 0.74 for the Asian countries (UNDP, 2004). By enhancing local human capital and modern infrastructure and improving other fundamentals for economic growth, a country is investing long term, since spillovers of foreign investment will feed into the domestic economy.

Third, the Latin American countries also failed to implement effective industrial policies as part of a long- term development framework. Generally speaking, Latin American countries have adopted a "the more the better" approach ${ }^{6}$ to FDI, with a strong focus on the balance of payments or external financing (ECLAC, 2000). They have not, in general, targeted FDI promotion or aimed it at specific national development goals, such as improving international competitiveness, deepening industrialization, promoting technology transfer and management practices, and so forth. The Latin American countries have also exhibited a clear lack of promotion and linkages between programmes (Willem te Velde, 2001, p. 28), which accounts for the absence of positive spillovers. Linkages are essential for channelling knowledge and skills from foreign affiliates to domestic firms (Battat, Frank and Shen, 1996).

\section{VI}

\section{The Irish model of FDI attraction}

\begin{abstract}
Ireland is a success story, with a history of steadily improving its locational advantages and competitiveness over time (it held fiftieth place in the mid-1990s) ${ }^{7}$
\end{abstract}

In 2001-2003 Ireland ranked fourth in the world as a recipient of FDI and its economic growth model has been hailed as an example of development. In the 1990s, Ireland was the best performing economy among the OECD countries (Barry, Bradley and Hannan, 1999), with one of the highest rates of per capita GDP in the world, low unemployment, stable economic and financial systems and a high standard of living. In 2005, Ireland ranked first in the quality of life index prepared by the Economist Intelligence Unit. ${ }^{8}$ A number of explanations have been advanced for the Irish economy's recent success, but the general consensus is that FDI has been crucial to its economic prosperity (Barry, 1999; Willem te Velde, 2001; O'Connor, 2001; Ruane and Gorg, 2000).

The Irish renaissance is attributable to a combination of historical developments and strategic

\footnotetext{
6 "The more the better" approach refers to the practice of attracting as much FDI as possible, while disregarding the quality of the investment to some extent.

${ }^{7}$ In the index prepared by UNCTAD on countries' performance as FDI recipients (UNCTAD, 2004 p.13).

${ }^{8}$ See The Economist (2005).
}

policies holistically applied by successive governments with a long-term vision of economic development.

\section{Historical developments}

One of the most important historical factors was the Great Famine, which instigated Ireland's long history of forced emigration. It has been acknowledged that Ireland's mass exodus during the first half of the nineteenth century left the task of building economic prosperity to future generations. The Irish population emigrated to countries that offered better economic prospects than their homeland (Barry, 1999, p. 25). Today, the Irish diaspora stands at 70 million, mostly residing in the United States, where 44 million claim Irish origins. Because of this, Ireland has always enjoyed special ties with the United States. Today, American technology firms have poured billions of dollars into Irish industries.

The second important historical development is the failure of trade protection policies employed in 19301960 in the context of the small Irish market. The Irish economy performed very poorly during this period, with an average growth rate of $1.67 \%$ (Ó Gráda and 
O'Rourke, 1996). The import substitution policies created an exclusively home-market oriented industry in which imports increased faster than exports, generating a balance-of-payments deficit. In view of the prosperity of other European countries, Ireland was obliged to move towards market-oriented policies. Its commitment to free trade was sealed with the AngloIrish Free Trade Agreement signed in 1966.

The third important development occurred in 1973, with Ireland's admission into the European Community (EC), known as the European Union (EU) since the entry into force of the Maastricht Treaty of 1992. Ireland's membership of the European Union has brought it great benefits in the form of trade relations and financial assistance. Since its entry, Ireland has received structural assistance through different programmes promoting economic and social cohesion. ${ }^{9}$ Financial support from the European Union helped Ireland to modernize its infrastructure, which contributed greatly to increasing its appeal as a location for FDI. From the late 1970s to the early 1990s, net transfers from the EU to Ireland represented between $4 \%$ and $7 \%$ of Ireland's GDP. EU financial support underpinned massive investment in infrastructure, for instance, US $\$ 60$ billion has been spent on modernizing telecoms infrastructure since 1982. The success of Ireland's economy will make the country a net contributor to the European Union in 2006.

\section{Strategic policies}

Ireland developed a strategic framework for national policy, encompassing industrial and macroeconomic policies on FDI, which has been crucial to its success in attracting FDI. Even more important, however, is the way it has used FDI as a method of economic growth. Willem te Velde's (2001) classification of industrial and macroeconomic policies allows us to identify the main strategic tools that Ireland has employed.

\section{(a) Industrial policies}

(i) Long-term strategic focus. In the 1960s, one of the most important decisions of policymakers was the setting of long-term economic development goals in the light of national priorities. Government policies focused on job creation in response to high unemployment and foreign investment was promoted as a generator of employment. In the absence of natural resources, the best thing Ireland could do to attract FDI

\footnotetext{
${ }^{9}$ See Barry, Bradley and Hannan (1999).
}

was educate and train the labour market in the use of high technology. For years, successive Irish governments maintained this long-term strategic approach and increased educational investments in technology, expanded the university system and created vocationally and technologically oriented institutions and national institutes of higher education.

(ii) Creation of an institutional framework for investment promotion. Ireland's framework for investment promotion is an essential component of its success in attracting inward FDI. The Industrial Development Agency, known as IDA-Ireland, has advocated for the formulation and effective implementation of marketing policies. Enterprise Ireland was created to foster new company start-ups and build linkages between multinationals and local industry. More recently, the Science Foundation of Ireland (SFI) has been established to promote the new Irish brand "knowledge economy" (Enterprise Ireland, 2004).

(iii) Competitive positioning. Its young educated workforce has played a key role in Ireland's economic success. Ireland has Europe's highest percentage of under- 25 population, at 37\%, according to Eurostat, the EU statistical office. Government policies continue to support education, to which they allocate $13 \%$ of the budget. Around $90 \%$ of secondary students finish school at 18 years of age, with $54 \%$ going on to higher education and about $65 \%$ of students going into the technology and business fields, which is the highest proportion in the OECD (OECD, 2003).

(iv) Targeting high-value added sectors. Through a policy of sectoral targeting, Ireland was able to create a good climate for investment for three high-value added sectors: information technology, the pharmaceutical industry and internationally traded services. In the last 20 years, Ireland has become fertile ground for technology and is known as the computer centre of Europe.

\section{(b) Macroeconomic Policies}

(i) Sound macroeconomic performance and prospects. The Irish economy has proven remarkably resilient in the era of globalization. Inflation has remained low and currently stands at around $2.02 \%$ per year (CSO, 2005), which is the lowest among the OECD countries. Recently, the government budget and the balance of trade have been in substantial surplus and this underpinned the adoption of a strongly pro-growth fiscal policy (see table 3). A pro-active fiscal policy has been one of the keys to creating an attractive location for FDI. The provision of grants and subsidies 
TABLE 3

Ireland: external trade

(Millions of dollars)

\begin{tabular}{cccc}
\hline Year & Imports & Exports & Trade surplus \\
\hline 1988 & $12,970.10$ & $15,623.90$ & $2,653.90$ \\
1989 & $15,597.80$ & $18,534.40$ & $2,936.60$ \\
1990 & $15,832.10$ & $18,203.90$ & $2,371.80$ \\
1991 & $16,317.20$ & $19,070.10$ & $2,752.90$ \\
1992 & $16,753.90$ & $21,260.20$ & $4,506.30$ \\
1993 & $18,899.70$ & $25,178.50$ & $6,278.80$ \\
1994 & $21,945.40$ & $28,890.90$ & $6,945.50$ \\
1995 & $26,180.90$ & $35,330.10$ & $9,149.20$ \\
1996 & $28,479.50$ & $38,608.90$ & $10,129.40$ \\
1997 & $32,863.50$ & $44,868.00$ & $12,004.50$ \\
1998 & $39,715.00$ & $57,321.80$ & $17,606.80$ \\
1999 & $44,327.10$ & $66,956.20$ & $22,629.10$ \\
2000 & $55,908.80$ & $83,888.90$ & $27,980.10$ \\
2001 & $57,384.20$ & $92,689.90$ & $35,305.70$ \\
2002 & $55,628.10$ & $93,675.20$ & $38,047.10$ \\
2003 & $47,864.60$ & $82,076.10$ & $34,211.50$ \\
2004 & $50,565.50$ & $84,160.10$ & $33,594.60$ \\
\hline
\end{tabular}

Source: CSO (2005).

and strong investment in promotion, together with the regime of low corporate taxes, have undoubtedly contributed greatly to good economic performance.

(ii) Open market economy. The failure of protectionist policies led to a broad national consensus regarding the direction of economic and industrial policy. Ireland has never been divided on this issue. There was no debate between the political left and right on the opening up of the economy, as both main political parties are conservative right of centre, with the differences between them not related to economic policy but rooted in the civil war of the 1920s.

(iii) Creating a propitious economic environment. Adding to the availability of a skilled labour force and infrastructure, Ireland devised fiscal and financial incentive schemes. Financial incentives are extended in the form of investment and training grants, low-interest loans, and so forth. Fiscal incentives are framed within the low corporate tax system, which is acknowledged being at the core of Ireland's appeal for multinationals (Ruane and Gorg, 2002 , p. 8). The tax system in Ireland remained unchanged for a long time. From 1954 to 1980, a zero tax rate applied to the profits of manufacturing industries. From 1980 on, a $10 \%$ applied to manufacturing profits, with firms that qualified for this rate in July 1998 entitled to pay tax at $10 \%$ until 2010. For newcomers (since 2003), a $12.5 \%$ tax rate applies to corporate trading income.

\section{(c) Other factors: the national consensus}

Since the late 1980s, Ireland has adopted a series of national agreements on wages and taxes as part of the Programme for National Recovery. The economic crisis in Ireland in the mid-1980s spurred discussions between government, employers and trade union leaders. The main negotiations, in which leading employers and labour interests were represented, gave rise to the Social Partnership Agreement, which was signed by the government, employers and trade unions. This tripartite agreement, which was renegotiable every three years, helped to moderate wage demands and lower inflation.

Underpinning all of this was a very conscious effort to ensure policy coordination at national and local levels. The acid test for any new policy initiative was an assessment of whether it would enhance or impede investment in Ireland, be the investors foreign or indigenous. This mindset was crucially important, since well-intentioned policy initiatives that were found to have potential for undesired or unintended negative effects on investment could then be rejected or modified accordingly. This holistic approach to development was very reassuring for foreign investors, as an indication of the importance that successive Irish governments attributed to their investments.

\section{The institutional framework of investment promotion in Ireland}

The investment promotion framework deserves the most credit for Ireland's successful drive to attract FDI, create linkages between foreign and local industry and upgrade its competitive advantages. The Irish model of investment promotion has encompassed activities ranging from public image campaigns, marketing strategies, development of financial and fiscal incentives and services for potential investors to fostering links between inward investors and the domestic industry. Recently, Ireland has focused on creating a new brand image as a knowledge economy. Three institutions have been established to this end: the Industrial Development Agency, in 1969; Enterprise Ireland, in 1993; and the Science Foundation of Ireland, in 2003.

\section{(a) Industrial Development Agency (IDA-Ireland)}

IDA-Ireland was created to carry out investment promotion activities. Its primary objective was to secure new investment from overseas for manufacturing and international services, in order to create jobs. Since its establishment, IDA-Ireland has played a key role in 
supporting and administering most of Ireland's investment promotion programmes. Although the agency's primary objective has become no less important over the years, the maximization of economic and social benefits deriving from foreign investment has also become central to its policy strategy.

(i) Sectoral targeting strategy. The development of strategies to attract high quality foreign investment has always been high on IDA-Ireland's agenda. The agency's intervention was instrumental in the investment decision of the first TNC to site a plant in Ireland, Digital Equipment Corporation. By 2004, more than 1,022 TNCs had located in Ireland, employing 128,946 workers. As shown in table 4, most of these companies are from the United States (478), Germany (140) and the United Kingdom (116), but FDI in Ireland comes from numerous sources.

TNCs are present in a wide range of activities, but most of the FDI in Ireland has gone to the pharmaceutical and health care sectors and to international financial services. Across all the FDI inflows to Europe, Ireland has attracted $41 \%$ of software projects, $31 \%$ of pharmaceutical and medical technology and $34 \%$ of pan-European shared services (IDA-Ireland, 2003 p. 5). Ireland's large pool of highly skilled labour has matched the requirements of FDI in high-technology projects. The presence of TNCs has significantly contributed to the standard of living in Ireland. For example, in 2003, TNCs paid an average annual salary of 37,000 (IDAIreland, 2003 p. 4).

(ii) Marketing. Through its network of overseas offices, IDA-Ireland markets the country's advantages for high-technology TNCs by emphasizing the competitiveness and stability of the economy, the skills base of its highly educated workforce, the favourable tax regime and the available financial incentives. The capability and experience of IDA-Ireland in successfully attracting foreign TNCs are widely recognized. ${ }^{10}$

As described in MacSharry and White (2000), ${ }^{11}$ the agency first began to target such sectors as biotechnology, computer software, electronics and healthcare in the early 1980s. It identified key firms within these sectors, established contacts and developed long-term relationships -lasting up to 10 years in some cases, including IBM and Intel- before the firms committed to establishing export platforms in Europe.

${ }^{10}$ See, for example, Loewendahl (2001).

11 This publication is co-authored by one of IDA-Ireland's former managing directors.
TABLE 4

Ireland: foreign investment, 2004

\begin{tabular}{|c|c|c|}
\hline $\begin{array}{l}\text { Country of } \\
\text { origin }\end{array}$ & $\begin{array}{l}\text { Number of } \\
\text { companies }\end{array}$ & $\begin{array}{c}\text { Total } \\
\text { employment }\end{array}$ \\
\hline Australia & 6 & 145 \\
\hline Austria & 7 & 305 \\
\hline Belgium & 13 & 954 \\
\hline Bermuda & 9 & 420 \\
\hline Canada & 16 & 960 \\
\hline China & 1 & 6 \\
\hline Denmark & 8 & 1,814 \\
\hline Finland & 4 & 399 \\
\hline France & 41 & 2,226 \\
\hline Germany & 140 & 11,158 \\
\hline Greece & 1 & 48 \\
\hline Israel & 1 & 63 \\
\hline Italy & 23 & 560 \\
\hline Japan & 32 & 2,639 \\
\hline Liechtenstein & 1 & 10 \\
\hline Luxembourg & 2 & 160 \\
\hline Netherlands & 41 & 2,933 \\
\hline Norway & 1 & 20 \\
\hline Other non-European & 3 & 84 \\
\hline Republic of Korea & 6 & 205 \\
\hline South Africa & 2 & 31 \\
\hline Spain & 3 & 14 \\
\hline Sweden & 14 & 2,230 \\
\hline Switzerland & 25 & 2,645 \\
\hline Taiwan Province of China & 1 & 7 \\
\hline Turkey & 2 & 5 \\
\hline United Kingdom & 116 & 6,824 \\
\hline United States & 478 & 90,230 \\
\hline Total & 1,022 & 128,946 \\
\hline
\end{tabular}

Source: Annual Employment Survey (Forfas, 2004).

In 1974-1975, indigenous firms provided two-thirds of all manufacturing jobs in Ireland and TNCs employed the remainder. By 1998-1999, however, TNCs accounted for almost half of all manufacturing jobs.

(iii) Investing in promotion. IDA-Ireland has invested heavily in promotion over the years, thanks to its considerable budget allocations. The average cost per job sustained in supported companies in 1996-2002 was estimated at 15,897 euros. According to the IDA Annual Report 2003, expenditure that year amounted to 155 million euros, of which $62 \%$ was spent on grants to industry, $22 \%$ on promotion and administration, and $6 \%$ on land and site development (IDA-Ireland, 2003). On the other hand, the Irish government collected a total of 2.6 billion euros in corporation tax from the FDI sector alone in 2003 and the total number of full time jobs created stood at 128,993 .

(iv) Facilitating information. Since its establishment, IDA-Ireland has expanded rapidly. Today 
it has a staff of 280, including 40 officers working in 13 overseas offices, who provide foreign investors with quality information and support network facilities in order to minimize bureaucratic costs.

\section{(b) Enterprise Ireland}

Enterprise Ireland was created to provide business support to indigenous Irish enterprises. This goal has been successfully achieved through promoting innovation and productivity, supporting the creation of new companies, encouraging enterprise development and providing business training. These are the key elements that have provided Irish companies with the means to compete successfully in international markets.

(i) Creating linkages. Since its establishment, Enterprise Ireland has played a significant and effective role in linking up foreign affiliates' sourcing requirements and the production profile of local suppliers. Enterprise Ireland has also encouraged the establishment of venture capital funds that have to a large extent transformed the domestic technology industry. Two prime examples are Iona Technologies and Parthus Technologies. The services that Enterprise Ireland has developed over the years are delivered through a network of 13 offices in Ireland and 34 overseas, from which it serves some 500 to 600 Irish firms at any given time. As part of its promotional activities, Enterprise Ireland proactively identifies international buyers through sales meetings, missions at home and abroad and trade fairs.

(ii) Targeting new high-level industry. In 2002, Enterprise Ireland launched the Building Biotech Business Strategy to promote new industry. Biotechnology was identified as an industry primed for growth that would fuel the Irish economy in years to come. Enterprise Ireland's strategy is designed to propel Irish industry toward becoming a biotech hub. The agency aims to create a new generation of companies in this industry, in order to keep Ireland on the technology map. For success in the biotechnology industry, the key factors identified are strong researchoriented universities, an educated workforce and State and corporate support (Enterprise Ireland, 2004). Enterprise Ireland has concluded that cutting-edge university research appears to be the most crucial asset and has therefore focused on supporting university research that is most likely to generate new knowledge, as the basis for new technologies and competitive enterprises.

\section{(c) Science Foundation Ireland}

Science Foundation Ireland (SFI) was created in 2003 to maintain competitiveness in the global economy. The Foundation was entrusted with the promotion of scientific research and industry innovation in order to foster Ireland's image as a knowledge economy. Knowledge has become the key message in FDI promotion, under the banner "Ireland, knowledge is in our nature". The role of SFI is to establish Ireland as a centre of research excellence in scientific areas that are strategically linked to economic development.

Policymakers view SFI as the agency that will secure Ireland's position at the fore of scientific development. In 2000-2006, SFI will provide 646 million euros to academic researchers, particularly in the areas of biotechnology and communications technology. SFI is seeking to attract scientists and engineers from around the world to develop a knowledge-based economy in Ireland.

\section{VII}

\section{Learning from the Irish model} and moving forward

The competitiveness of the Asian countries threatens the Latin American countries' position in the global market, not only because the region has failed to attract quality investment but also because it has neglected relevant factors that could have made FDI an instrument for growth. The challenge for the Latin American countries now is to move on from capturing predominantly resource- and market-seeking investment towards successful attraction of the efficiency-and technological asset-seeking varieties. Although not all aspects of the Irish model are applicable to Latin America, a number of important aspects are to be considered. 


\section{Setting long-term economic development goals}

All countries need a long-term plan for economic development that includes FDI as a driver of economic growth. It has taken Ireland about 30 years to build up a competitive and advantageous market site for FDI. In the mid-1990s, Ireland ranked fiftieth in market performance for FDI. Today it ranks fourth among all the countries (UNCTAD, 2004 p. 13) and was positioned seventh in terms of inbound FDI projects in the first half of 2005 (oco Consulting, 2005).

\section{Identifying comparative advantages}

Ireland's model is extraordinary in that a small country with little indigenous resources has grown its competitive advantages through effective industrial policies and FDI advocacy. Ireland has invested heavily in human infrastructure (Durkan, FitzGerald and Harmon; 1999). Ireland's competitive advantage lies in its young, well-educated population. The availability of a highly educated workforce trained in advanced technology not only helped to attract FDI, but also raises the quality of the investment secured (Lall, 1997).

Latin America's competitiveness, by contrast, has been built up around its comparative advantages in natural resources and cheap labour, but the fact remains that the Latin American labour force is not as specialized or highly trained as that of its competitors. For instance, educational level and workforce training had much to do with successful promotion of FDI on the part of China, Malaysia, Singapore and Taiwan Province of China (Addison and Heshmati, 2003). Latin America must invest in human capital if it is to make the shift from resource-seeking to efficiency-seeking investment. A pool of skilled labour is not only a determinant of FDI in an economy but also a necessary part of its ability to absorb the spillover effects (Willem te Velde, 2001).

Porter (1998, p. 7) has argued that, "The enduring competitive advantages in a global economy lie increasingly in local things such as knowledge, relationships, motivation that distant rivals can't match."

Latin America's location should enhance its comparative competitiveness. Although distances have become less important with globalization, a country's location is still fundamental in an era of global competition (Porter, 2000).

\section{Promoting comparative advantages effectively}

Ireland's comparative advantages alone would not have sufficed to secure quality FDI inflows without IDAIreland's promotion of its image as an attractive market site. The approach pioneered by IDA-Ireland now heads the list of effective models for investment promotional agencies (IPAs) (Morisset and Andrews-Johnson, 2005). In recent years, the establishment of an IPA has been an important part of governments' development strategies in Latin America and elsewhere (Morisset, 2003), yet few have been successful.

The following are important elements of Ireland's IPA that could be applied in Latin America.

(i) The provision of a one-stop-shop system for investors is one of the main recommendations for any IPA. Using this approach, IDA-Ireland provides quality information and support networks that effectively save foreign investors time and money (Ruane and Gorg, 2000. p. 6). IDA-Ireland staff make it their business to know the key decision makers in other government departments and local authorities. With this network of contacts they are well positioned to guide investors through the procedures for obtaining the permits and approvals Irish law requires.

(ii) The establishment of a single government agency outside the civil service, together with the onestop-shop scheme, has been crucial to IDA-Ireland's successful promotion work. The fact that the agency is operated independently, although owned by and accountable to the Government, increases its flexibility and enhances its credibility among investors (Loewendahl, 2001, p. 8).

(iii) Ireland has an aggressive investment agency. Through its network of overseas offices, IDA-Ireland has marketed the country as an attractive location for high-tech firms by spotlighting the competitiveness and stability of its economy, the favourable tax regime, the skills base of Ireland's highly educated workforce, dutyfree access to the EU markets and the financial incentives on offer. IDA-Ireland's investment generation activities have also included targeted telephone calls, presentations and the provision of research to electronic and pharmaceutical companies in the United States, Europe and Japan (Willem te Velde, 2001, p. 37).

(iv) IDA-Ireland has also received substantial government support for promoting the country as a market site for FDI. Empirical findings point to a positive correlation between the effectiveness of a promotion agency and the amount of money spent on promotion. 
IDA-Ireland has provided financial support in the form of grants, subsidies and training. The adoption of a similar practice in Latin America should be accompanied by oversight to avoid potential for corruption (Loewendahl, 2001, p. 17).

(v) The establishment of the National Linkage Programme in Ireland improved the agency's promotional skills and has efficiently created linkages between local and foreign industry. While IDA-Ireland has played an efficient promotional role in policy advocacy, Enterprise Ireland has fostered and promoted indigenous Irish industry and foreign investment. Building links between multinationals and the local industry has also contributed to the success of spillover and, hence, economic growth. One of the most effective ways to generate positive spillovers in Latin America would be to create linkages.

(vi) In order to promote its competitive advantages effectively, Ireland had to target specific sectors and adopt a future perspective. The most recent FDI-oriented industrial policy measure was the creation of Science Foundation Ireland and the latest strategy in competitiveness-building has been to provide university training in IT and biotechnology for the labour force.

\section{Creating an attractive economic environment}

Effective promotion is important in order to attract FDI. Promotion can be counterproductive in a country that offers a poor investment climate, however (Morisset, 2003, p. 18). The trade liberalization, privatization and deregulation carried out in Latin America since the 1980s have proven to be insufficient. Clearly, further stimulation is required to create a stable and an attractive economic environment for FDI. The factors that helped create an attractive environment for FDI in Ireland included:

(i) Economic stability, clear macroeconomic policies and the establishment of a sophisticated financial system.

(ii) Ireland's system of low corporate tax is recognizably one of its most important incentives for inward investment.

(iii) Access to third country markets.

(iv) The corporate environment.

(v) The quality of life.

\section{VIII}

\section{Conclusions and recommendations}

Attracting foreign investment has become a new means of achieving economic growth and poverty reduction for many countries. It is a futile endeavour, however, to attract FDI in the absence of the necessary conditions for economic development. The creation of a competitive market site requires efforts in many areas, but for FDI to be an instrument of economic growth it must be approached via holistic policies framed within a national economic development plan based on longterm development goals. In Latin America, the assumption that FDI would contribute positively to the economy and generate spillovers into local industry has not been borne out. The Irish experience shows the importance of effective industrial and macroeconomic policies and a technically sophisticated promotional framework in order to secure FDI that can feed into national economic development.

Much of the FDI received by the Latin American countries in recent years has represented the acquisition of existing companies, sometimes as part of privatization programmes. Greenfield investment must be the next target, in order to create new plants, increase productive capacity and expand economic value. Such investments are usually seen as having a stronger direct impact on national development. Just as Ireland targeted United States companies because of historical, cultural and linguistic links, Latin American countries should approach European nations whose heritage they share. European investors are increasingly important in the FDI market and Spain is the leading investor in the region today. Latin America should also consider Asian countries which are initiating or deepening foreign investment processes (such as China of the Republic of Korea, respectively).

Given how effective Ireland's strategic framework for promoting quality FDI has proven to be, Latin America would do well to devote energetic efforts to designing an investment promotion system.

Investment agencies should also coordinate and build linkages between FDI and local industry. Lack of 
linkages has been one of the main impediments to the absorption of spillover from FDI in Latin America. It is also important to invest more in education and training, since the traditional determinants of FDI have become less influential and investment in human capital seems to be the crucial factor today. If Latin America competes for investment solely on the basis of its natural resources and in the confines of its local markets, its position in the international market for FDI will be further weakened.

Bibliography

Addison, T. and A. Heshmati (2003): The New Global Determinants of FDI Flows to Developing Countries, WIDER Discussion Papers, No. 2003/45, New York, United Nations University.

Aitken, B. and A. Harrison (1999): Do domestic firms benefit from direct foreign investment?, American Economic Review, vol. 89, No. 3, Nashville, Tennessee, American Economic Association.

Athukorala, P. and S. Rajapatirana (2003): Capital inflows and the real exchange rate: a comparative study of Asia and Latin America, The World Economy, vol. 26, No. 4, Oxford, United Kingdom, Blackwell Publishing.

Balasubramanyam, V., M. Salisu and D. Sapsford (1996): Foreign direct investment in EP and IS countries, The Economic Journal, vol. 106, No. 434, Oxford, United Kingdom, Blackwell Publishing.

Barry, F. (ed.) (1999): Understanding Ireland's Economic Growth, London, Macmillan Press.

Barry, F., J. Bradley and A. Hannan (1999): The European dimension: the single market and structural funds', in F. Barry (ed.), Understanding Ireland's Economic Growth, London, Macmillan Press.

Battat, R., I. Frank and X. Shen (1996): Suppliers to Multinationals: Linkage Programs to Strengthen Local Companies in Developing Countries, Foreign Investment Advisory Service Occasional Paper, No. 6, Washington, D.C., World Bank.

Borensztein, E., J. de Gregorio and J.W. Lee (1998): How does foreign direct investment affect economic growth?, Journal of International Economics, vol. 45, No. 1, Amsterdam, Elsevier.

Blomström, M. (2001): The Economics of International Investment Incentives, Paris, Organisation for Economic Co-operation and Development (OECD).

Blomström, M. and A. Kokko (2003): The Economics of Foreign Direct Investment Incentives, NBER Working Paper, No. 9489, Cambridge, Massachusetts, National Bureau of Economic Research.

Cso (Central Statistics Office Ireland) (2005): External Sector, www.cso.ie/releasespublications, June.

Church, J., Gandal and D. Krause (2002): Indirect Network Effects and Adoption Externalities, CEPR Discussion Papers, No. 3738, London, Centre for Economic Policy Research (CEPR).

De Mello (1997): Foreign direct investment in developing countries and growth: a selective survey, Journal of Development Studies, vol. 34, No. 1, London, Routledge, October.

Dunning, J. (1988): The eclectic paradigm of international production: a restatement and some possible extensions, Journal of International Business Studies, vol. 19, No. 1, Houndsmills, Palgrave Macmillan Journals.

Durkan, J., D. FitzGerald and C. Harmon (1999): Education and growth in the Irish economy, in F. Barry (ed.), Understanding Ireland's Economic Growth, London, Macmillan Press.

ECLAC (Economic Commission for Latin America and the Caribbean) (2001): Foreign Investment in Latin America and the Caribbean. 2000 Report, LC/G.2125-P, Santiago, Chile. United Nations publication, Sales No. E.01.II.G.12.

(2003): Foreign Investment in Latin America and the Caribbean, 2002, LC/G.2198-P, Santiago, Chile. United Nations publication, Sales No. E.03.II.G.11.
(2004): Foreign Investment in Latin America and the Caribbean, 2003, LC/G.2226-P, Santiago, Chile. United Nations publication, Sales No. E.04.II.G.54.

(2005): Foreign Investment in Latin America and the Caribbean, 2004, LC/G.2269-P, Santiago, Chile. United Nations publication, Sales No. E.05.II.G.32.

Enterprise Ireland (2004): Аnnual Report, Dublin, June. (2005): Annual Report, Dublin, June.

Ethier, W.J. (1998): The new regionalism, The Economic Journal, vol. 108, No. 449, Oxford, United Kingdom, Blackwell Publishing.

Forfás (2005): Annual Employment Survey 2004, Dublin.

Hallward-Driemeier, M. (2003): Do Bilateral Investment Treaties Attract Foreign Direct Investment? Only a Bit and They Could Bite, Policy Research Working Paper Series, No. 3121, Washington, D.C., World Bank.

IBM-PLI (2005): Global Investment Location Database (GILD). IDA-Ireland (Industrial Development Agency-Ireland) (2002): Annual Report 2002, Dublin, December.

(2003), Annual Report 2003, Dublin, December. (2004), Annual Report 2004, Dublin, December.

Jenkins, R. (2002): The labour market effects of globalization in South Africa, document presented at the TIPS workshop on Globalization, Production and Poverty, Johannesburg.

Kinoshita, Y. and N. Campos (2004): Estimating the Determinants of Foreign Direct Investment Inflows: How important are Sampling and Omitted Variable Biases?, BOFIT Discussion Papers, No. 10/2004, Helsinki, Bank of Finland Institute for Economies in Transition (BOFIT).

Kolstad, I. and E. Villanger (2004): How Does Social Development Affect FDI and Domestic Investment?, Working Paper, No. 22080, Bergen, Chr. Michelsen Institute (CMI).

Lall, S. (1997): East Asia, in J. Dunning (ed.), Governments, Globalization and International Business, Oxford, Oxford University Press.

Loewendahl, H. (2001): A framework for FDI promotion, Transnational Corporations, vol. 10, No. 1, UNCTAD/ITE/IIT/ 27, New York, United Nations Conference on Trade and Development (UNCTAD), April.

MacSharry, R. and P. White (2000): The Making of the Celtic Tiger: the Inside Story of Ireland's Boom Economy, Cork, Mercier Press.

Mauro, P. (1995): Corruption and growth, Quarterly Journal of Economics, vol. 110, No. 3, Cambridge, Massachusetts, The MIT Press.

Morisset, J. (2003): Does a Country Need a Promotion Agency to Attract Foreign Direct Investment? A Small Analytical Model Applied to 58 Countries, World Bank Policy Research Papers, No. 3028, Washington, D.C., World Bank, April.

Morisset, J. and K. Andrews-Johnson (2005): The Effectiveness of Promotion Agencies at Attracting FDI, Foreign Investment Advisory Service Occasional Paper, No. 16, Washington, D.C., World Bank.

Noorbakhsh, F., A. Paloni and A. Youssef (2001): Human capital and FDI inflows to developing countries: new empirical evidence, World Development, vol. 29, No. 9, Amsterdam, Elsevier, September. 
Nunnenkamp, P. and J. Spatz (2002): Determinants of FDI in developing countries: has globalization changed the rules of the game?, Transnational Corporations, vol. 11, No. 2, UNCTAD/ITE/IIT/31, New York, United Nations Conference on Trade and Development (UNCTAD), August.

O'Connor, P. (2001): Foreign Direct Investment and Indigenous Industry in Ireland: Review of Evidence, ESRC Working Papers, No. 22/01, Sussex, University of Sussex.

Ó Gráda, C. and K. O’Rourke (1996): Living Standards and Growth, Working Paper WP00/14, Department of Economics, Dublin, University College Dublin.

oco Consulting (2005): The eye of the tiger: Ireland winning overseas investment, October, in www.locomonitor.com.

OECD (Organisation for Economic Co-operation and Development) (2003): Education at a Glance: OECD Indicators 2003, Paris.

Oman, C. (2000): Policy Competition for Foreign Direct Investment: a Study of Competition among Governments to Attract FDI, Paris, Organisation for Economic Co-operation and Development (OECD), March.

Porter, M. (1998): Clusters and the new economics of competition, Harvard Business Review, vol. 36, No. 6, Boston, Harvard Business School.

(2000): Location, competition, and economic development: local clusters in a global economy, Economic Development Quarterly, vol. 14, No. 1, Thousand Oaks, California, Sage Publications.

Rodrik, D., A. Subramanian and F. Trebbi (2002): Institutions Rule: Institution, Integration and Geography, Harvard University Working Papers, available in http://ksghome.harvard.edu/ $\sim$ drodrik/papers.html.

Ruane, F. and H. Gorg (2000): European integration and peripherality: lessons from the Irish experience, The World Economy, vol. 23, No. 3, Oxford, United Kingdom, Blackwell Publishing, March.

Saggi, K. (2000): Trade, Foreign Direct Investment and
International Technology Transfer: A Survey, Policy Research Working Paper, No. 2349, Washington, D.C., World Bank.

The Economist (2005): The world in 2005, available in http:// www.economist.com.

UNCTAD (United Nations Conference on Trade and Development) (1999): World Investment Report 1999: Foreign Direct Investment and the Challenge of Development, UNCTAD/WIR/ 1999, New York, United Nations. United Nations publication, Sales No. E.99.II.D.3.

(2003): World Investment Report 2003: FDI policies for development: national and international perspectives, UNCTAD/WIR/2003, New York, United Nations. United Nations publication, Sales No. E.03.II.D.8.

(2004): World Investment Report 2004: The Shift Towards Services, UNCTAD/WIR/2004, New York, United Nations. United Nations publication, Sales No. E.04.II.D.33.

(2005a): World Investment Report 2005: Transnational corporations and internationalization of $R \& D$, New York, United Nations. United Nations publication, Sales No. E.05.II.D.10.

(2005b): Foreign Direct Investment Statistics 2005, in http:/ /www.unctad.org/Templates/Page.asp?intItemID=1923\&lang=1.

UNDP (United Nations Development Programme) (2004): Human Development Report 2004: Cultural Liberty in Today's Diverse World, New York, July.

Willem te Velde, D. (2001): Policies Towards Foreign Direct Investment in Developing Countries: Emerging Best Practices and Outstanding Issues, London, Overseas Development Institute, March.

World Bank (2005): World Development Report 2005: A Better Investment Climate for Everyone, Washington, D.C.

Zhang, K.H. (2001): Does foreign direct investment promote economic growth? Evidence from East Asia and Latin America, Contemporary Economic Policy, vol. 19, No. 2. Oxford, Oxford University Press, April. 